\title{
Loss of outer arm dynein components produce specific and separable phenotypes in zebrafish
}

\author{
R Burdine*, CE Slagle \\ From First International Cilia in Development and Disease Scientific Conference (2012) \\ London, UK. 16-18 May 2012
}

Structural and functional defects in cilia lie at the heart of several human genetic disorders, including polycystic kidney disease, male sterility, retinal degeneration, respiratory complications, and organ laterality defects. It is therefore crucial to study various aspects of cilia biology so as to better understand the exact molecular causes of these disorders. In our current study, we utilize a novel zebrafish mutant called flanders to study the relationship between organ laterality defects and kidney cyst development. flanders is expressed in both ciliated Kupffer's vesicle, important for left-right patterning, and in the pronephros/kidney. However, unlike other laterality mutants we have studied, flanders homozygotes display a strong laterality phenotype without an associated strong kidney cyst phenotype, despite the flanders gene showing high homology to a structural component the outer arm dynein complex. To determine why flanders does not appear to be critical in pronephric cyst formation, we looked for other genes that may function redundantly in this tissue. We show that a flanders paralog, $c c d c 114$, plays a minor role in organ laterality but interacts with flanders during cyst development. Loss of flanders or ccdc114 reduces cilia beat frequencies in both Kupffer's vesicle and the kidney even though each protein only produces phenotypes thought to originate in one of these tissues. Our data suggest that outer arm dynein complex composition may regulate a functional difference between motile cilia in Kupffer's vesicle and those in the kidney. We will discuss our ongoing work on this mechanism.

Published: 16 November 2012 * Correspondence: rburdine@princeton.edu
Princeton University, USA
Submit your next manuscript to BioMed Central and take full advantage of:

- Convenient online submission

- Thorough peer review

- No space constraints or color figure charges

- Immediate publication on acceptance

- Inclusion in PubMed, CAS, Scopus and Google Scholar

- Research which is freely available for redistribution 